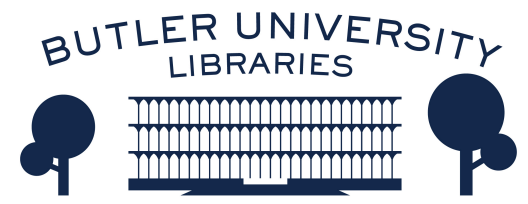

Journal of Hindu-Christian Studies

\title{
An Aesthetics of Hospitality: Embodied Religious Experience and Scholarly Engagement in Hindu-Christian Studies
}

\author{
Katherine C. Zubko \\ University of North Carolina Asheville
}

Follow this and additional works at: https://digitalcommons.butler.edu/jhcs

\section{Recommended Citation}

Zubko, Katherine C. (2015) "An Aesthetics of Hospitality: Embodied Religious Experience and Scholarly Engagement in Hindu-Christian Studies," Journal of Hindu-Christian Studies: Vol. 28, Article 5.

Available at: https://doi.org/10.7825/2164-6279.1604

The Journal of Hindu-Christian Studies is a publication of the Society for Hindu-Christian Studies. The digital version is made available by Digital Commons @ Butler University. For questions about the Journal or the Society, please contact cbauman@butler.edu. For more information about Digital Commons @ Butler University, please contact digitalscholarship@butler.edu. 


\section{An Aesthetics of Hospitality: Embodied Religious Experience and Scholarly Engagement in Hindu- Christian Studies}

\section{Katherine C. Zubko University of North Carolina Asheville}

IT is with pleasure that I accepted an invitation to be a respondent to a panel that explores the interstices between aesthetic theory and practice. As an ethnographer who is trained in Sanskrit aesthetics, I am particularly interested in what happens in the spaces of contact and crossover between various embodied religious traditions. For me, these explorations mostly have been located in the study of Bhārata Nātyam, a rhythmic dance form through which artists traditionally enact the stories of Hindu gods and their devotees. In contemporary practice, the themes and practitioners of this dance form reflect a much broader spectrum of adaptation that includes various religious and secular contexts. I have posited that the interpretive reframing of the aesthetic of bhakti rasa, a devotional mood, by performers serves as a pivotal foundation for why and how choreographers and dancers move across religious boundaries in their choices of choreographic themes and participation in the dance form. I am humbled by Michelle Voss Roberts' kind words about the small contributions I have made to the ongoing dialogue on aesthetics and pluralism in her introduction.

The excellent work that we heard about today from Michelle Voss Roberts and Patrick Beldio provide vivid case studies and analyses that help further our queries through the lens of aesthetics. I plan to raise a few questions for each author but also want to suggest an emergent common theme that may best be described as an aesthetics of hospitality. Both of the papers touch upon how artists and

Katherine C. Zubko is Associate Professor of Religious Studies at University of North Carolina Asheville. Her areas of expertise include aesthetics, ritual, performance and embodied religion in South Asia. She received her Ph.D. in West and South Asian Religions from Emory University in 2008. Zubko is the author of Dancing Bodies of Devotion: Fluid Gestures in Bharata Natyam(Lanham: Lexington Books, 2014), as well as several articles, most recently "Dancing the Bhagavadgita: Embodiment as Commentary" in the Journal of Hindu Studies. Her work was recently recognized through receiving a Scholarly and Creative Achievement Award for 2014-15 at UNC Asheville. Current research interests include exploring the bodied aspects of conflict transformation, and the long-term pedagogical impact of field site visit pedagogies. Zubko currently serves on the steering committee for the Teaching Religion unit of the American Academy of Religion and the advisory board of the Society for Hindu-Christian Studies.

Journal of Hindu-Christian Studies 28 (2015):33-39 
artistic forms host sites that mediate and invite experiences of divinity seeped in a multiplicity of possible ritual, spatial and theoretical grammars. These models of fluid aesthetic hospitality, while unique to their own local contexts, also may help challenge us as scholars to consider the ways we engage in and create hospitable spaces for our own inter-religious queries in Hindu-Christian Studies.

Aesthetics, as both a theoretical and practical category of analysis, is an effective framework to explore a variety of topics. On the surface level, aesthetics may refer to style, or for others, the form and relative sense of beauty associated with that form as guided by particular principles that are culturally determined. The issue with this initial, and often unintentionally narrow view is that form is positioned as subservient to the primacy of an idea or underlying meaning being conveyed through that form. Being aware of this limiting definition, many scholars, such as those we have heard from today, seek language and categories that take into account how aesthetic form and meaning inform and shape each other to avoid placing conceptual meaning at the top of a hierarchy of value when dissecting aesthetic engagement.

Adding another level, the intersections explored between aesthetics and religion/theology/philosophy in these papers also reflect a mutual symbiosis, rather than aesthetics being the handmaiden of religious belief. This panel is based on the premise of taking aesthetics seriously as a co-creative partner in understanding religious experience that points us towards the interactive, constantly shifting, emergent expression and meaning within particular contexts. The aesthetic space is one of dynamism, potentiality and co-existence in ways that provoke insights, challenge categories of thought, and point towards the ambiguities of religious expression and embodied experience trying to literally make sense of divinity/sacrality in relation to humanity. It is in the study of aesthetics that we gain another window on lived, embodied religion on the ground, engaging sacred dimensions of human experience through the senses as a meeting point with the contemplative transcendent, as our first author Michelle Voss Roberts adeptly points our attention to.

In Voss Roberts' paper, we get a succinct overview of the way rasa, often glossed as aesthetic taste or flavor, provides insight into her theological comparative project, as not only an analytical category, but also a practical one. Rasa theory, starting with the Nātyaśāstra onwards, precisely parses the ingredients of enacted references to context and catalysts (vibhāvas), physical-emotional responses (anubhāvas) and transitory emotions (vyabhicārïbhāvas). When these elements are mixed well and in the right proportion, the outcome then dramatically evokes a primary emotion (sthāyibhāva, often shortened to bhāva) on stage. But this is not the end of the theory, as its success hinges upon the degree to which that bhāva is enjoyably experienced, or tasted, by an audience member as one of eight (later nine) rasas, including fear, disgust, compassion and most prominently, love. Rasa operates on a strategy of universalization of human emotional experience expressed through the body that becomes efficacious when the mechanisms of aesthetic distance are repersonalized through the experiential connections made by each individual audience participant. Mark Doty echoes this idea in his 
meditation on still life paintings and poetry by noting how the most deeply affecting aesthetic engagement offers us "intimacy and distance at once." ${ }^{1}$ In other words, to be attentively absorbed in this aesthetic tension is to be both more of ourselves in relation to what is most sacred, as made possible by being a part of the wider human condition simultaneously. Rasa theory struck the imagination of many South Asian philosophers/theologians because of its perceived similitude to the elements and process of physical-emotional human response involved in experiencing a taste of the divine, as based on an initial distanced universalization that makes possible a range of intimate dimensions.

Voss Roberts' detailed comparison raises new questions about the special role aesthetics plays in providing experientially grounded language that speaks to the shifting relationship between two primary modes of religious experience: peaceful, transcendent aspects of contemplation, on the one hand, and the tumultuous embodied potentialities of desire/eros/käma on the other. Desire has been a primary metaphor in describing some forms of ultimate blissful transcendence, such as the painful ecstasy of the penetrative spear of God's love lodged in the heart of Teresa of Ávila ${ }^{2}$ and the intentional imitation of the amorous love of the gopis for Kṛṣna in Gaudìya Vaiṣnavism. ${ }^{3}$ At the same time, there have also been several strands of religious experience that do not publically claim desire, but still use the language and experience of desire in more understated ways.

Abhinavagupta is one of these theologians who found śanta, the peaceful rasa, to be better suited as a descriptor for religious experience, even though as Voss Roberts adeptly notes, he is writing from a tantric perspective that often embraced the role of desire. Sānta for Abhinavagupta is considered more conducive to mokșa (liberation), ānanda (bliss), and other aspects of idealized religious experience, but where does that leave śrngāra, or the erotic rasa, as the most dominant rasa pointed to by not just many theologians and mystics, but also performers, even if reframed through bhakti? If the union of śrngāra either experienced or yearned for from a place of separation "remains on the palate" to color one's experiences of the ever-unfolding world and the religious experiences therein, as Voss Roberts notes regarding Abhinavagupta, how does this śrngāra inform śānta, and vice versa?

There is something important here about not seeing rasas as static, but seeing them in relation to each other that grounds religious experience in embodied, sensory ways of being. I began to see through Voss Roberts' careful analysis a way to view Abhinavagupta's language about śānta as being supported by reference to yet another rasa -- the rasa of wonder, or adbhuta rasa. According to Malini Srinivasan, one of the Bhārata Nāṭyam dancers with whom I have worked, adbhuta rasa is the most primary rasa, even above śrngāra and śānta, because of its facility as a human response to engaging with the divine. ${ }^{4}$ The tracings of this rasa can be found in Abhinavagupta and Kulkarni's language of "imaginative delight" and "pure joy" that in many ways brings śānta and śrngāra into dialogue on a worldly, sensory level that is not too abstract or too carnal, but just right.

Jyoti Sahi, the visual artist discussed in Voss Roberts' paper, reflects this interaction between śānta and śrngāra in a parallel way to Abhinavagupta, marking śānta as the most 
important rasa, but also using language and forms that highlight "humanity's longing," and a dynamic action connecting the bodied sufferings of Jesus to struggles of and within the communal body, as bound together though language of union. This is a combination of śānta and śrngāra whose interactive tension is held together through the wonder that is enabled through aesthetic expression and encounter that Sahi, for one, dwells within and works from.

Based on this reading, I would like to hear more about how "wonder" is positioned or found in Abhinavagupta and Jyoti Sahi's work. If all rasas aim originally at creating a universalized space for receptivity, is the rasa of wonder an advantageous aesthetic choice to mark the process or effects of the repersonalization of religious experience, bridging the gap between receptive distance and personal engagement?

In what ways do understated or hidden aspects of śrngāra inform or interact with śānta in the theoretical or practical aesthetics of Abhinavagupta and Sahi? In both Hindu and Christian contemporary performances, śrnigāra has been eschewed by many for its potential of being too vulgarized, or inappropriate. Which other rasas are underplayed in Christian religious experience, whether designated as theological or performative, and what supporting rasas may be hidden underneath those choices of erasure? Rather than relying on medieval expressions of śrngāra, what in contemporary Christian experience claims śrngāra fully and how is it expressed aesthetically?

On a different note, I want to broaden the inquiry into one of hospitality on several levels. How do we create inviting universalized spaces for aesthetic, sensory experiences to inform understandings of personal engagement with the transcendent? How does the rasa of wonder that sensorially is receptive to the religious experiences framed primarily by śānta and śrngāra shape the formation of a grammar of hospitality to our own scholarly inquiries in Hindu-Christian Studies? If we take the rasa formula for a moment, which vibhāvas (physical contexts/catalysts), anubhāvas (physicalemotional responses) and vyabhicārībhāvas (transitory emotions) are conducive to creating inviting spaces for inter-religious exchanges, scholarly or otherwise to be tasted/engaged? How can we learn to be more refined sahrdayas (with heart) as scholars engaged in dialogical comparisons?

I think Voss Roberts has pointed us to a very important application of the repersonalizing effects of contemporary interpretations of rasa for not only our attention to the embodied aesthetic dimensions of the religions we study, but also how we go about that study.

Our second paper, by Patrick Beldio, adds several other dimensions to our panel based on astute and balanced assessments of two complementary case studies that demonstrate an aesthetic fusing ideal of androgyny. Fusing brings together gendered opposites, a process that offers a model of spiritual growth enacted and expressed well through visual cultures. Beldio argues that the fusing model, as opposed to a splitting model that involves creating gendered order out of an originally undifferentiated androgynous form, both of which are proposed by Eliade and Doniger, is a more analytically apt model for his comparative work. 
The first context Beldio discusses is rooted in the spiritual relationship between Pondicherry gurus Sri Aurobindo and the Mother (Mirra Alfassa) who were believed to embody the masculine and feminine human forms of the divine as a single avatar in two bodies. Central to their religious experience, described as Integral Yoga, is a vision of human ascension and then reintegration of divinity into the worldly realm as lived through an "unsexed" supramental body. The application and expression of the supramental body envisioned in Integral Yoga, and demonstrated only in part through the androgynous coexistence of Aurobindo and the Mother, is aesthetically engaged in two ways according to Beldio: the paintings of Huta as guided by the Mother who was drawing from Aurobindo's Savitri poem, and as reflected in the architecture of the Golconde Dormitory that remains part of the Pondicherry Ashram.

The dynamics of śānta and śrngāra that I noted in Voss Roberts' paper on models of religious experience seem to be embedded in this larger vision of Integral Yoga, as well. An experiential union with the transcendent is followed by descent back into the world of human form infused with divinity as modeled by Kṛṣna, a blissful form that has both embraced and transformed desire beyond carnality. Just as Aurobindo has made the tranquil transcendent at home in his supramental body, a process expressed in his poetry, the aesthetic vision of this transformative experience paralleled by the Mother has been hosted through the painter and paintings of Huta. The aesthetic moments that Beldio brings to our attention here highlight transfigured bodies that reflect a certain amorphousness, but are also "natural", even as they expand across shared bodies of experiential truth and aesthetic vision/expression in a type of continual porousness of personhood, time and place. This is exemplified between Aurobindo and the Mother, as well as the Mother and Huta, as both dyads offer expressions of present, processual experience and a complete future vision at the same time. With the architecture of Golconde dormitory, Beldio extends his analysis to show us how places connected to the Pondicherry Ashram also are defined by an ongoing intimate porousness between people and environment. And yet this porousness exists through being constructed of the most stable, solid and literal concreteness of structure, fusing androgyny in spatial dimensions as well.

With all these layers of permeability, I sense that underlying the development of Integral Yoga itself is an assumption that these aesthetic experiences are rooted in particular times and continue to be interacted with and informed by later students or devotees, and thus are constantly evolving. Based on this observation, I am curious to know more about how devotees engaged with these paintings/drawings at the time they were made, and what has happened to them now? What role does an aesthetic form created out of and meant to be ever evolving and integrative play in this continuing Aurobindo tradition, especially since the process of integration never ends in Integral Yoga?

In the second case study Beldio examines, Francis and Clare of Assisi demonstrate another model of fusing androgyny also in two physically separate bodies. Here, porousness is shared in terms of both the renunciatory values and contemplative practices embedded in understandings of śānta, and the desirous 
śrngāra-laden visions of Clare in interaction with Francis related to simultaneously as both mother and lover. The difference between splitting and fusing androgyny that Beldio hinges his analysis on includes androgyny within each of these individuals of Francis and Clare and across or between them in shared bodily practices, clothing, dwelling and worship spaces that bear on their larger conjoined interactive performance of saintliness that is magnified because of their conjoined nature. This is an important broadening of personhood that points us to understudied aspects of materiality/material culture that are part of the connective tissue of lived, and in this case inextricably shared religious experience.

In thinking through the categories of splitting and fusing androgyny, as an ethnographer I wonder about the effects of these experiences and aesthetic expressions on practitioners and devotees. How does a fused androgyny invite people into relationship with gurus or saints? By presenting shifting, evolving gender undifferentiated or shared spaces that inherently assume by their nature porous interaction, are there any ways that

\section{Notes}

${ }^{1}$ Mark Doty, Still Life with Oysters and Lemon (Boston: Beacon Press, 2001), 6, 67.

${ }^{2}$ One of the most famous passages on desire and transcendence describes Teresa's vision of an angel appearing to her: "In his hands I saw a great golden spear, and at the iron tip there appeared to be a point of fire. This he plunged into my heart several times so that it penetrated to my entrails. When he pulled it out, I felt that he took them with it, and left me these images and permeable spaces, in either the Pondicherry or Assisi contexts unintentionally leave people out?

More broadly, in what ways does the model of splitting or fusing inform our understandings of Hindu-Christian Studies? Do we welcome more dialogue through setting the Hindu and Christian aspects side-by-side, bringing order out of the often muddy chaos of the study of comparative religion? What emerges within scholarly observations that highlight apparent fusings of Hindu and Christian practices and ideas in more undifferentiated spaces that help inform our understanding? In what ways do either of these two models create hospitality for scholarly exchange?

Both of our authors have finely calibrated their particular lens of aesthetics to illuminate unseen dynamics of religious experience and challenge us to ask new questions. Beyond the value found in each study as it is understood in its direct localized context, I also appreciate how each author offers us insight into an aesthetics of hospitality that bears on how we do comparative work in Hindu-Christian Studies.

utterly consumed by the great love of God. The pain was so severe that it made me utter several moans. The sweetness caused by this intense pain is so extreme that one cannot possibly wish it to cease, nor is one's soul then content with anything but God." The Life of Saint Teresa of Ávila, translated by J.M. Cohen (New York: Penguin, 1957), 210.

3 Rūpa Gosvāmin notes in the Bhaktirasāmrtasindhu that "Passion (rāga), which is naturally sweet, is the highest access to the beloved (i.e., Kṛṣna)" (1.2.271), and “Amorous 
Bhakti is that which leads the thirst for sexual enjoyment to its perfect state, since is it undertaken exclusively for the pleasure of Kṛșna alone. It is perfectly accomplished and brilliantly displayed in the gopis of Vraja. Their particular perfect love (prema) attains a special sweetness. Because it is connected with the various divine love sports, the wise call it amorous (kāma)" (1.2.283-4). See David Haberman, Acting as a Way of Salvation: A Study of Rāgānugā Bhakti Sādhana (Oxford: Oxford University Press, 1988), 157-8.

${ }^{4}$ See Katherine C. Zubko, Dancing Bodies of Devotion: Fluid Gestures in Bharata Natyam (Lanham, MD: Lexington, 2014), 181-198. 